\title{
Summary of Alternative Methods Intended for Imaging of Weak-Phase Objects in Transmission Electron Microscopy
}

\section{R.M Glaeser}

Life Sciences Division, Lawrence Berkeley National Laboratory, University of California, Berkeley, CA 94720

Information about the structure of a weak-phase object is encoded mainly in the phase, but hardly at all in the amplitude, of the exit wave for electrons that are transmitted through a thin specimen. As a result, in-focus bright-field images of such specimens show virtually no intensity modulations - i.e. very little image contrast. There are, however, numerous other imaging methods that do provide access to the phase (i.e. structural) information that exists in the exit wave (see Table 1). Defocused bright-field (i.e. phase-contrast) imaging is currently the default method used to determine the structures of unstained, cryo-EM specimens of biological macromolecules. While this method is remarkably powerful, it is nevertheless in some senses also remarkably crude. Contrast transfer is quite poor, for example, for the low spatial frequencies that carry most of the information about the size, shape, and location of an object Contrast transfer also suffers from sign reversals (and accompanying zeros), as well as from a damped envelope, when the amount of defocus is increased in order to improve the contrast transfer at low frequencies.

Many alternative imaging methods have been investigated in the past. More recently, there has been a spurt of innovation that has produced quite a number of proposals to realize Zernike phase contrast. In each case the goal is to avoid the shortcomings inherent in defocus-based phase contrast without introducing new shortcomings that are worse than those that one hopes to overcome. This talk will (1) review what are believed to be the technical difficulties associated with each alternative listed in Table 1 and (2) propose potential solutions (if any) that could still be investigated. The completeness of this list is limited, of course, to information that is known at this point, and more particularly by the knowledge and the point of view of the author!

The alternatives listed in Table 1 can be thought of as falling into four classes. (1) Arguably the most intuitive way to recover phase information is by holography. Defocus-based phase-contrast imaging is, in effect, a realization of Gabor's initial proposal regarding holographic imaging [1]. (2) Darkfield imaging (and more recently diffractive imaging) exploits the fact that undetectable phase modulations in the exit wave are converted into measurable intensity modulations by Fraunhofer diffraction. (3) Intensity modulations can also be produced by masking-off parts of the diffracted wave (use of an aperture in the back focal plane); among these methods, use of the Foucault (or knife-edge) aperture is a standard way to evaluate phase-imperfections in the figure of lenses or mirrors. In electron microscopy, Foucault imaging is perhaps better known as single-sideband imaging. (4) Quite recently, two proposals by Boersch [2] for ways to realize Zernike phase contrast in the TEM have finally begun to approach forms that are suitable for routine data collection. This success, in turn, has inspired a flurry of newer ideas, as is reflected in the last 6 rows of Table 1.

References

[1] D. Gabor, Nature 161 (1948) 777.

[2] H. Boersch, Zeitschrif fur Naturforschung Section a 2 (1947) 615. 
Table 1. Imaging methods that can recover structural information encoded solely in the phase of the exit wave transmitted through a weak-phase object

\begin{tabular}{|c|c|c|}
\hline PHYSICAL PRINCIPLE & TECHNICAL DIFFICULTIES & POTENTIAL SOLUTIONS \\
\hline $\begin{array}{l}\text { Traditional defocus- } \\
\text { based phase contrast } \\
\text { (Gabor's in-line } \\
\text { holography) }\end{array}$ & $\begin{array}{l}\text { Poor SNR at low spatial } \\
\text { frequencies } \\
\text { Oscillating CTF at high spatial } \\
\text { frequencies }\end{array}$ & $\begin{array}{l}\text { None are known at this time } \\
\text { [low spatial frequencies remain } \\
\text { poor; filling in zeros in the CTF } \\
\text { requires additional images] }\end{array}$ \\
\hline $\begin{array}{l}\text { Bi-prism interferometer } \\
\text { (off-axis holography) }\end{array}$ & $\begin{array}{l}\text { Specimen charging causes the } \\
\text { phase of the reference wave and } \\
\text { that of the object wave to fluctuate } \\
\text { independently }\end{array}$ & None are known at this time \\
\hline Dark-field & $\begin{array}{l}\text { Loss of small-angle scattered } \\
\text { electrons within the bright-field } \\
\text { cone }\end{array}$ & None are known at this time \\
\hline Diffractive imaging & $\begin{array}{l}\text { Unknown issues with respect to } \\
\text { (1) radiation dose and (2) } \\
\text { background scattering }\end{array}$ & $\begin{array}{l}\text { Develop the quantitative analysis } \\
\text { needed to clarify these unknowns }\end{array}$ \\
\hline $\begin{array}{l}\text { Microfabricated single- } \\
\text { sideband (Foucault- } \\
\text { contrast) aperture }\end{array}$ & $\begin{array}{l}\text { Prone to charging when hit by the } \\
\text { electron beam }\end{array}$ & $\begin{array}{l}\text { Heat the aperture } \\
\text { Use an anticontaminator } \\
\text { Cool the aperture }\end{array}$ \\
\hline $\begin{array}{l}\text { Charging of a target } \\
\text { placed in the back focal } \\
\text { plane }\end{array}$ & $\begin{array}{l}\text { Rapid oscillation of the CTF at low } \\
\text { spatial frequency } \\
\text { Poor control/reproducibility of the } \\
\text { charging effect }\end{array}$ & None are known at this time \\
\hline Thin-film phase plate & $\begin{array}{l}\text { Prone to charging when hit by the } \\
\text { electron beam } \\
\text { Even initially good (carbon) films } \\
\text { begin to charge with age }\end{array}$ & $\begin{array}{l}\text { Same anti-charging solutions as for } \\
\text { the single-sideband aperture } \\
\text { Alternative amorphous materials } \\
\text { Investigate surface processing }\end{array}$ \\
\hline $\begin{array}{l}\text { Microfabricated } \\
\text { electrostatic devices }\end{array}$ & $\begin{array}{l}\text { Prone to charging } \\
\text { May require enlarged electron } \\
\text { diffraction patterns for low spatial } \\
\text { frequencies }\end{array}$ & $\begin{array}{l}\text { Same anti-charging solutions as for } \\
\text { the single-sideband aperture } \\
\text { Add optics to magnify the diffraction } \\
\text { pattern }\end{array}$ \\
\hline $\begin{array}{l}\text { Microfabricated } \\
\text { magnetic devices }\end{array}$ & $\begin{array}{l}\text { Prone to charging when hit by the } \\
\text { electron beam } \\
\text { May require enlarged electron } \\
\text { diffraction patterns }\end{array}$ & As for electrostatic devices \\
\hline $\begin{array}{l}\text { Pixelated electrostatic } \\
\text { mirror }\end{array}$ & $\begin{array}{l}\text { Currently limited to lower } \\
\text { microscope voltages }\end{array}$ & $\begin{array}{l}\text { Develop the needed high-voltage } \\
\text { technology }\end{array}$ \\
\hline $\begin{array}{l}\text { Light-optical } \\
\text { (ponderomotive } \\
\text { potential) devices }\end{array}$ & $\begin{array}{l}\text { Requires either very intense laser } \\
\text { beams or rather low electron } \\
\text { energies }\end{array}$ & $\begin{array}{l}\text { Combine DTEM with pulsed lasers } \\
\text { Decelerate the electrons } \\
\text { Power build-up cavities }\end{array}$ \\
\hline
\end{tabular}

